\title{
Diffusion of Big Data Analytics Innovation in Managing Natural Resources in the African Mining Industry
}

Surajit Bag, Department of Supply Chain Management/ Information Systems, Rabat Business School, International University of Rabat, Technopolis Rabat-Shore Rocade Rabat-Salé, Morocco

(iD) https://orcid.org/0000-0002-2344-9551

Gautam Srivastava, GL Bajaj Institute of Management and Research, Greater Noida, India

Shivam Gupta, Department of Information Systems, Supply Chain Management and Decision Support, NEOMA Business School, France*

(iD https://orcid.org/0000-0002-2714-4958

Saito Taiga, Graduate School of Economics, The University of Tokyo, Tokyo, Japan

\begin{abstract}
The study draws upon the ethical theory of organizing to elucidate the links between ethical climate antecedents, organizational practices, and consequences. The authors also integrated organizing vision theory to examine the influence of diffusion of big data analytics innovation on sustainable business practices. The results indicate that organizational trust has a significant positive impact on ethics training and ethics audit, which is critical to South Africa's mining industry. Furthermore, the results indicate that ethical leadership is positively related to ethics training and ethics audits. Findings show that ethics training and ethics audit are positively related to sustainable business practices. Findings indicate that the vision constructed by community members is positively related to the diffusion of big data analytics innovation. They also found that the diffusion of big data analytics innovation is positively related to sustainable business practices. Lastly, findings show that sustainable business practices are positively related to firm performance.
\end{abstract}

\section{KEYWORDS}

Big Data Analytics, Ethical Theory of Organizing, Mining, Natural Resources, Organizing Vision Theory

\section{INTRODUCTION}

The mining industry is the backbone of South Africa's economy. The mineral energy complex is critical to the growth of South Africa. Gold ore, copper ore, manganese, iron ore, and platinum ore are the minerals generally processed by mining companies in Africa (Marais et al., 2018). The longterm sustainability of mining companies has generated interest among a diverse set of stakeholders (Kusi et al., 2016). The mining industry's greatest obstacles are minimizing the negative effects on 
the environment and keeping workers engaged in a safe way (Laing et al., 2019). The mining industry requires meticulous tactical preparation and proper strategic management to solve its operational challenges (Hilson \& Murck, 2000).

Presently, South Africa's mining industry is undergoing technological transformation to improve productivity. To increase the productivity of mining companies, appropriate training and development programs are needed for mining and mineral processing workers. South Africa is exploring the potential of innovative technologies in the mining industry (Kaplan, 2012). The mining industry must evaluate its sustainability performance and demonstrate that advanced technology deployment is having a positive effect on the industry (Badri \& Boudreau-Trudel., 2021).

Stakeholder pressure and regulations serve as a driving power for the mining industry's long-term growth. Environmental, social, and economic concerns, as well as the well-being of all stakeholders, should guide sustainable development (Azapagic, 2004). The South African mining industry's sustainable development problem focuses on exploring the relationship between organizational goals, corporate practices, and their effect on safety, health, community relations, and the environment. In the mining industry, there should be a proper stakeholder participation policy and targeted communications (Palabora Mining Company, 2021).

The well-being and health of workers and contractors are critical to the mining industry's longterm viability in South Africa (Exxaro Powering Possibility, 2021). Employees must have faith in the company to ensure its long-term viability. Organizational trust has a big effect on long-term development. To build organizational trust, ethical leadership is essential (Demirtas, 2015). Ethical leadership improves workers' cultural perspectives and fosters an atmosphere of trustworthiness, integrity, caring, and fairness within the organization. To build a trust-based environment, there should be a social exchange partnership between an organization's top management and its staff. Ethical leaders empower their employees through ethical training and support (Demirtas, 2015). This training provides freedom to the employees and makes them responsible for their work and organization. Employee trust in the company is strongly associated with ethical leadership (Engelbrecht et al., 2017). Organizational commitment and ethical leadership are inextricably linked. Inside the organization, organizational commitment generates trust. Ethical leadership improves organizational efficiency and assists in the achievement of organizational goals (Abuzaid, 2018).

Allen et al. (2005) highlighted the importance of ethics training for business students. It creates instrumental values and organizational trust. However, a dearth of empirical studies has examined the impact of organizational trust and ethical leadership on ethics training. Ethics training improves a person's ability to make the best decision when it comes to ethical issues. Employee empathy is critical in ethics training because it boosts organizational trust (Gomez et. al., 2020). Ethics could be developed through reinforcement and ethical action. Ethics training enables an organization's employees to learn the organization's code of ethics. Employees who receive ethics training can make better decisions when it comes to ethical issues (Kancharla \& Dadhich, 2021).

Ethics auditing is essential for monitoring ethical principles within an organization. Ethics audits ensure that the organization's fundamental standards are followed, which improves employee loyalty. Ethics auditing varies from organization to organization, but its practices are associated with the sustainable performance of the firm (Yazdani \& Murad, 2015). Hence, research is needed to examine the influence of organizational trust and ethical leadership on ethics training and ethics auditing in the mining industry.

Additionally, transparency is a concern in South Africa's mining industry. It is the responsibility of the leaders to enhance transparency in the mining industry. It has been reported that many decisions are made without following the proper protocol and policies. The problem is exacerbated by a lack of communication and organizational trust (Leonard, 2019). Trust is a crucial aspect that affects a company's overall success (Alaaraj et al., 2018). Organizational trust enhances and facilitates cooperation and the exchange of information and ideas, enabling problem and conflict-resolving discussion. Organizational trust is critical for cultivating a positive workplace environment. An 
organization's management uses organizational trust as a motivator for its workforce. The organization's biggest challenges are the maintenance of a high level of organizational trust (Chams-Anturi et al., 2019). Organizational trust cannot be achieved without effective organizational leadership. Openminded, inspirational, and rational leadership is essential when implementing sustainable business practices within the organization (Chong et. al., 2018). However, empirical studies are lacking, and to fill the gap, a study is, therefore, necessary to determine the association between organizational trust and ethical leadership in shaping the sustainable business practices of the South African mining industry. Hence, $\mathbf{R Q 1}$. What is the role of organizational trust and ethical leadership in shaping sustainable business practices and the final impact on firm performance in the South African mining industry?

The use of information and data systems enhances the coordination among the employees of the organization, and social media data are useful for demand forecasting as well (Iftikhar \& Khan, 2020; Zulkefly et al., 2021). The use of technologies increases the efficiency of the workers within the organization (Kim \& Miranda, 2018). The community members surrounding an organization play a critical role in shaping the firm sustainability goals. A company must have a collectively constructed community idea for using information technologies to improve decision-making (Miranda, 2015).

Big data analytics is penetrating deeply into the organization process and not only improving the decision-making power of the managers but also proving useful for environmental performance evaluations (Song et al., 2018). Big data analytics enhances the understanding of the organization's strengths and weaknesses and improves coordination among stakeholders (Mikalef et al., 2019).

Although the source of the mine's surrounding environmental problems is directly related to the mine/mineral processing plant, society/the community members face the consequences. Community members are aware of the benefits of big data-driven innovation in enhancing environmental performance, so they can exert pressure on companies to apply this technology for sustainability purposes. Literature has pointed out that the community can develop coercion mechanisms to boost the application of big data analytics (Gaffoor et al., 2020; Bag et al., 2021b). For example, the vision of community members for digitalization can lead to achieving sustainable development goals. However, the mechanism behind the diffusion of big data analytics in achieving business sustainability in the South African mining industry is vague. Hence, $R Q 2$. How can the vision constructed by community members aid in the diffusion of big data analytics innovation?

Section two covers the theoretical underpinnings followed by the hypothesis development in section three. Section four deals with the research methods employed in this study and section five present the analysis of the data. Section six presents the discussion and the conclusions drawn from the empirical study.

\section{THEORETICAL UNDERPINNINGS}

\subsection{Ethical Theory of Organization}

The modern theory of organization is focused on conventional ethical principles and a recent advanced scientific approach. The essential concept of organizational values should include components of business ethics (Demirtas, 2015). Organization theories play an extremely important part in today's globalized world. Organization theory assists in the establishment of a balance between a company's business ethics and its financial performance. In recent years, the focus on ethics has changed from job goals to an organization's values. An organization's primary duty is to implement and instill ethical principles within the organization. As a consequence, ethical leadership is an important factor for a firm to achieve its objectives (Nedkovski et al., 2017; Kancharla \& Dadhich, 2021).

According to the ethical theory of organization, the organization and society should have a trust based relationship. Mutual trust remains an integral part of a company's ethical culture. Ethics is a prerequisite for generating trustworthiness and satisfaction among company workers. Organizational trust creates a positive environment for ethical training (Yazdani \& Murad, 2015). 
Ethical training promotes the organization's ethical and moral behavior. Monitoring the positive effects and promoting an ethical climate within the organization requires strong leadership. Ethical leadership and organizational trust are important antecedents for the ethical theory of an organization and have a significant impact on ethics training and auditing (Yazdani \& Murad, 2015). Organizational ethics could be maintained within the organization by ethical auditing. Ethical auditing is a crucial tool for controlling illegal practices within an organization. Within the organization, both ethical training and ethical auditing should be ongoing processes. Ethical auditing and training lead to sustainable business practices. Sustainable business practices increase the effectiveness and productivity of an organization, which has a direct impact on the firm's performance (Yazdani \& Murad, 2015).

\subsection{Organizing Vision Theory}

The adoption of communication technologies and information systems improves the organization's capacity to make fast decisions (Bag et al., 2021b). Appropriate information systems improve organizational efficiency and competitiveness. To achieve the organization's vision, there should be proper cooperation among community members. The vision consists of the whole organizational approach to achieve sustainable business performance. The organizational vision theory is focused on the different actors' contributions to community organizations (Standing et al., 2017). An organization could achieve its vision by using big data analytics. Big data analytics assists the company in value creation by providing empirical assistance (Yoo \& Roh, 2021). Big data analytics could be used to analyze the organization's strengths and weaknesses. The outcomes of big data analytics assist the company in supporting strategic decisions for long-term sustainability. Big data analytics enhance sustainable business practices within the organization (Mikalef et al., 2019). To improve the organization's sustainable business practices, appropriate and constructive relationships between employees and other members are required. Sustainable business practices improve an organization's efficiency and productivity, which has a direct effect on the company's performance.

Based on the preceding discussion, a theoretical model has been developed (see Figure 1).

Figure 1. Theoretical model

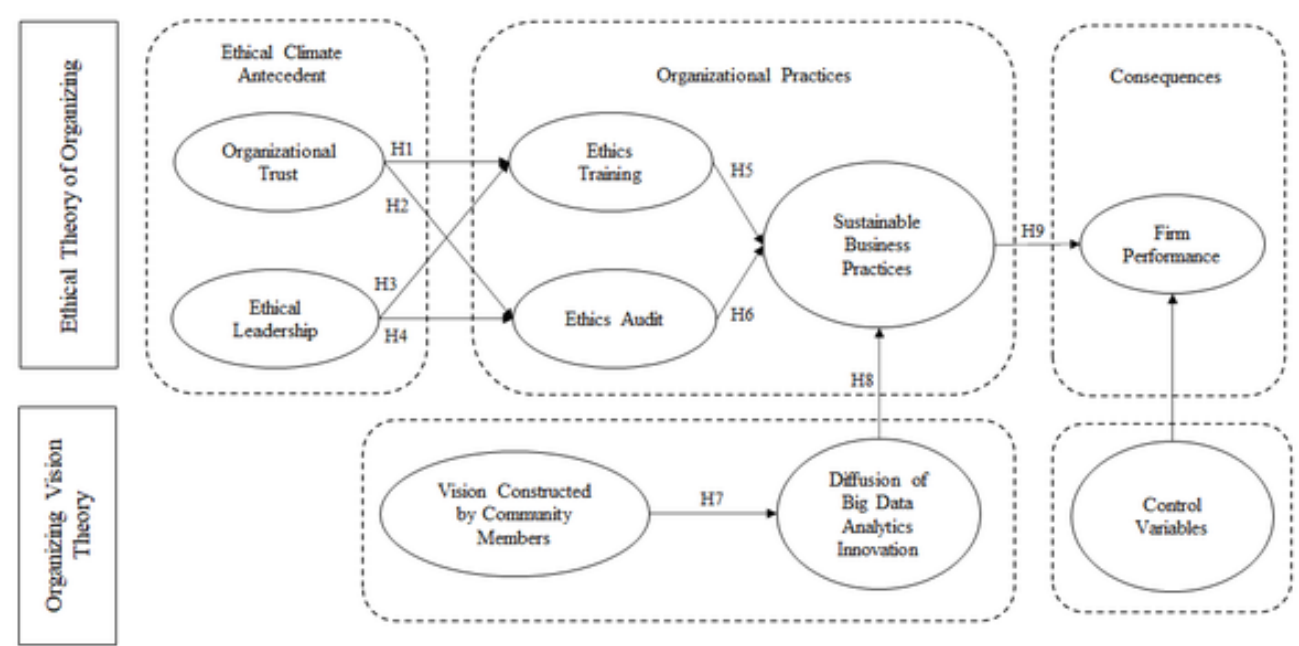




\section{HYPOTHESIS DEVELOPMENT}

\subsection{The Relationship Between Organizational Trust and Ethics Training}

Trust is a crucial strategic action within an organization (Ilyas et al., 2020). It is necessary to take a cognitive approach towards a company's trustworthiness. In companies, trust creates a positive environment (Kancharla \& Dadhich, 2021). The importance of trust in maintaining a stable and balanced relationship between superiors and subordinates cannot be overstated (Schoorman et al., 2007). Inter-organizational trust is established through organizational trust. Trust could be generated by a written agreement backed by ethical conduct (Vélez et al., 2008). Employee perceptions of an organization's ethical environment are reflected in its ethical climate. Ethical leadership is an important factor in predicting the trustworthiness of an organization's management. Employees can see the ethical policies of a company through trust, which acts like a mirror (Nedkovski et al., 2017). The ethical principles of an organization are created through trustworthiness. Organizational trust and ethical leadership are intertwined. There is a significant relationship between organizational trust and ethical leadership (Pučètaitè et al., 2014). Ethical leadership encourages ethical training within the company to build employee trust. It is critical to building trust to inspire workers to achieve organizational objectives. According to the time factor hypothesis, time is crucial in the creation of an organization's ethical model. The decision should be made quickly within the organization, and the implementation should be completed within a reasonable amount of time (Schoorman et al., 2007). Thus, we put forth the following hypothesis:

Hypothesis 1: Organizational trust is positively related to ethics training.

\subsection{The Relationship Between Organizational Trust and Ethics Audits}

Trustworthiness improves the organization's ethical leadership. Organizational trust is essential for the development of moral values within the organization's employees (Audi et al., 2016). The effectiveness of trust is strongly associated with ethical principles. If the company values trustworthiness, workers have a more optimistic outlook toward it (Brown et al., 2005). An organization's prestige is enhanced by the trust. Capacity, honesty, and benevolence are the three main factors used to assess trust (Mehta et al., 2020). An ethics audit is carried out to see how the company adheres to a code of conduct and ethical standards. Ethical auditing is an ongoing procedure that takes place within an organization to keep workers' perceptions of the company optimistic. Ethics auditing is necessary for the organization's fundamental principles to be upheld. Ethical auditing is critical for forming and designing capitalism that is based on moral values (Everett \& Tremblay, 2014). Thus, we put forth the following hypothesis:

Hypothesis 2: Organizational trust is positively related to ethics audits.

\subsection{The Relationship Between Ethical Leadership and Ethics Training}

Ethical leadership is characterized by the conduct of personal behavior and interpersonal relationships that are normatively acceptable (Spangenberg \& Theron, 2005). Corporate principles underpin the ethical leadership model. It is the primary duty of responsible leadership to uphold the organization's ideals and beliefs. Ethical leadership is connected to a motivational process that helps employees perform efficiently. With the assistance of the social learning process, ethical leadership improves the psychological empowerment of workers. It is regarded as ethical training because it assists in the development of ethical principles among employees (Dust et al., 2018). Moral principles must be instilled in an organization's workers, which requires ethical training (Sterling \& Gass, 2017). By implementing ethical practices within the company, ethical training strengthens the involvement of workers in achieving corporate goals. Ethical training is the foundation of every organization's effort to maintain a healthy working atmosphere that can boost productivity (Singh et al., 2019). 
Thus, we put forth the following hypothesis:

Hypothesis 3: Ethical leadership is positively related to ethics training.

\subsection{The Relationship Between Ethical Leadership and Ethics Audits}

Grojean et al. (2004) argued that to develop a sustainable working environment, the leadership needs to have an ethical framework. According to the leadership theory, moral managers are viewed as having ethical leadership qualities such as honesty, good faith, and trustworthiness (Liu \& Ren, 2017). Leaders must become role models in the organization and demonstrate high moral behavior in their work (Grojean et al., 2004). Many studies have previously emphasized the importance of ethics for top management/leaders (Ozgener, 2009). Ethical leadership indicates the actions, discussions, and other demonstrations by leaders that include suitable norms (Ozgener, 2009). Leaders must demonstrate normatively suitable conduct, and this should be reflected in their actions and attitudes towards their followers (Brown et al., 2005). Good values are the basis of moral behavior and it is therefore important that leaders cultivate ethical dimensions in the organization so that a positive environment is created that would be appreciated by the stakeholders. Moreover, organizations have certain formal procedures and policies related to ethics, including ethics audits (Demirtas, 2015).

Ethical auditing is one of the most critical actions and supervisory mechanisms for an organization's long-term success (Arel et al., 2012). It is a mechanism to check the progress made after implementing important policies. An ethics assessment is done to determine whether the organization's legal culture and policies are being followed. It is the leader's primary duty to supervise ethics audits within the organization (Liu \& Ren, 2017). Ethical auditing improves the organization's transparency. Ethical leadership shapes socialized behavior, which also influences the discipline needed to conduct ethics auditing regularly (Demirtas, 2015). Thus, we put forth the following hypothesis:

Hypothesis 4: Ethical leadership is positively related to ethics audits.

\subsection{The Relationship Between Ethics Training and Sustainable Business Practices}

An organization's long-term vision cannot be pursued without employing sustainable business practices. Developing sustainable business practices within an organization is a difficult task. Both the economic and social perspectives should be considered when developing sustainable corporate practices. Sustainable business practices are focused on five elements: collaboration, foundation, guidance, reconnection, and outcome from an ethical standpoint (Svensson et al., 2010). Appropriate business models take into account more ethical and long-term business practices. They prioritize the interests of all stakeholders. Ethical and technical innovations are fueled by sustainable business practices. They contribute to the long-term success of businesses as well as society (Raut et al., 2019). Thus, we put forth the following hypothesis:

Hypothesis 5: Ethics training is positively related to sustainable business practices.

\subsection{The Relationship Between Ethics Audits and Sustainable Business Practices}

Ethics audits are essential in the mining business due to the involvement of multiple processes and stakeholders. The ethical behavior of employees influences the organization's reputation and hence should be monitored regularly. Ethical issues in the mining business need to be resolved quickly as they can cause ripple effects in the entire supply chain. Ethical auditing ensures that the company adheres to a set of rules and procedures (Vanclay et. al., 2013). Ethical audits take into account both social and environmental aspects. Ethics auditing is a procedure that focuses on moral standards, 
values, and the code of ethics (Bringselius, 2018). Therefore, ethics audits can improve sustainable business practices (Svensson et al., 2010). Thus, we put forth the following hypothesis:

Hypothesis 6: Ethics audits are positively related to sustainable business practices.

\subsection{The Relationship Between the Vision Constructed by Community Members and the Diffusion of Big Data Analytics Innovation}

The diffusion of innovation theory was proposed by E. M. Rogers in 1962 and explains how an idea/ product comes to be diffused in a particular group of people or society. The outcome of this process is the adoption of the unique idea, behavior, or item. Inventors, new entrants, the sharing economy, the older generation, and big players are various types of adopters. When promoting an innovation, different approaches are used by firms to attract each category of the adopter. Nonetheless, a few of the most important factors that affect the adoption of an innovative product/technology are the relative benefit, flexibility, difficulty, innovative tools, and controllability, and are all important factors to consider. Maroufkhani et al. (2020) explained big data analytics adoption using the diffusion of innovation theory. According to the literature, a coerced society creates a coercion system that forces BDA use through economic or political force. Further coercion forces play an important role in BDA adoption for sustainable business (Standing et al. 2017; Dubey et al., 2019). Thus, we put forth the following hypothesis:

Hypothesis 7: The vision constructed by community members is positively related to the diffusion of big data analytics innovation.

\subsection{The Relationship Between the Diffusion of Big Data Analytics Innovation and Sustainable Business Practices}

For effective and safe business practices, smart business organizations have increasingly gained recognition. Big data is one of the most important technologies for improving an organization's productivity and efficacy. Big data analysis facilitates effective planning, resource conservation, and productivity enhancement. Big data processing examines large data sets to uncover hidden patterns. The information generated through big data enhances the sustainability of a firm (Ren et al., 2019). Big data analytics is used for statistical forecasting, accelerating real-time decision-making, as well as to rethink corporate practices to meet potential challenges. The diffusion of big data analytics is essential to meet future challenges and accelerate corporate business practices (Wolfert et al., 2017). Big data improves corporate practices within the organization. One of the fastest-growing strategies for making business practices more competitive and efficient is big data analytics. Big data is increasing the efficiency of business processing. It increases competitiveness, productivity, efficiency, sustainable business practices, and societal development (Papadopoulos et al., 2017).

Thus, we put forth the following hypothesis:

Hypothesis 8: The diffusion of big data analytics innovation is positively related to sustainable business practices.

\subsection{The Relationship Between Sustainable Business Practices and Firm Performance}

Businesses are changing their strategies in response to the challenges of sustainability. Long-term goals affect strategic decisions within the organization, so operationalizing sustainability is a significant issue. The company's previous success, scale, and sustainability factors all influence an organization's sustainability business practices. The cost of technology deployment is used to measure long-term 
sustainability and firm performance (Schrettle et al., 2014). The relationship between sustainable business practices and firm performance varies from country to country. It is determined by cultural and economic disparities. There is no universally recognized connection between firm success and long-term management practices. The performance of the firm does not depend only on financial performance but also takes into account the social, economic, and environmental performance (Goyal et al., 2013). Sustainable business practices lead to long-term growth and improve the firm's productivity. Best practices that recognize employee benefits improve competitive advantages and have a positive effect on business performance. All stakeholders put tremendous pressure on global companies to uphold fair business practices and improve their performance (Laskar and Maji, 2018).

Thus, we put forth the following hypothesis:

Hypothesis 9: Sustainable business practices are positively related to firm performance.

\section{RESEARCH METHODS}

\subsection{Construct Operationalization}

The latent constructs for this study are Organizational Trust (ORT); Ethical Leadership (ETL); Ethics Trainings (ETT); Ethics Audit (ETA); Sustainable Business Practices in Mining Companies (SBP); Firm Performance (FIP); Vision Constructed by Community Members (VCC); and Diffusion of Big Data Analytics Innovation (DBA). Details of the constructs can be seen in the Appendix.

\subsection{Data and Method}

52 items were used to measure the latent constructs. Literature indicates that 20 samples for every item can be used and we, therefore, selected a total of 1040 samples. These samples were selected randomly from Directory No. D1/2016 named "Operating mines and quarries and mineral processing plants in the Republic of South Africa, 2016” Directorate: Mineral Economics.

We used a structured questionnaire which was developed using a Likert-type scale (five-points), where 1 means "strongly disagree", 2 means "agree", 3 means "neutral", 4 means "agree", and 5 means "strongly agree".

In May 2020, a pilot study was carried out by selecting 50 samples from the above-mentioned sampling frame. The link for the online questionnaire was shared with 50 employees from mining companies. After a month, we received 30 responses and then checked the reliability, validity, and goodness of fit; the results were found to be satisfactory. No items were removed or altered based on the pilot survey.

Based on the confidence gained from the pilot survey, we started the main survey in early July 2020, and the online questionnaire link was shared with 1040 potential respondents. We selected two participants from every company. By the end of July, we had received 114 responses, and after doing phone follow-ups, we received an additional 194 responses before the end of September 2020. We used a Google form-based questionnaire and the settings did not allow for any incomplete submissions. We stopped accepting responses after receiving 308 responses.

We checked the minimum sample size requirement using WarpPLS version 7.0 software. The inverse square root method indicates 279 , and the gamma-exponential method shows 261 . We, therefore, met the minimum sample requirement criteria, since we are far above this number (i.e., 308) and eligible for hypothesis testing. A similar approach has been taken in previous studies (e.g., Bag et al., 2021c).

The demographic profile of the people who participated in the survey is presented in Table 1 and Table 2. The respondents' work field and experience indicate that 30 percent of responses are from mines and quarries and 69 percent are from mineral processing units. 
Table 1. Respondents work domain and experience

\begin{tabular}{|c|c|c|c|c|}
\hline \multirow[b]{2}{*}{ Work Domain } & \multicolumn{4}{|c|}{ Work Experience } \\
\hline & $\begin{array}{c}\text { Less than } 10 \\
\text { years }\end{array}$ & $10-20$ years & $>20$ years & Total \\
\hline Mines and Quarries & - & 17 & 76 & 93 \\
\hline Mineral processing & - & 26 & 189 & 215 \\
\hline Others & - & 0 & 0 & 0 \\
\hline Total & - & 43 & 265 & 308 \\
\hline
\end{tabular}

Table 2. Different organizational roles and employees' strength

\begin{tabular}{|l|l|l|l|l|l|l|}
\hline \multicolumn{1}{|c|}{ Role in the Organisation } & \multicolumn{1}{c|}{$\begin{array}{c}\text { Less } \\
\text { than 100 }\end{array}$} & \multicolumn{1}{|c|}{$\mathbf{1 0 0 - 3 0 0}$} & \multicolumn{1}{|c|}{$\mathbf{3 0 1 - 5 0 0}$} & $\mathbf{5 0 1 - 1 0 0 0}$ & $\begin{array}{c}\text { More } \\
\text { than 1000 }\end{array}$ & Total \\
\hline CIO/Technology Director & - & - & 1 & - & 1 & 2 \\
\hline Chief Procurement Officer & - & - & - & 3 & 6 & 9 \\
\hline Senior VP/VP & - & - & - & 22 & 3 & 25 \\
\hline $\begin{array}{l}\text { Head of Business Unit or } \\
\text { Department }\end{array}$ & - & - & - & 78 & - & 78 \\
\hline Manager & - & - & 3 & 119 & 49 & 171 \\
\hline Data Analyst & - & - & - & - & 18 & 18 \\
\hline Data Scientist & - & - & - & - & 3 & 3 \\
\hline Consultant & - & - & - & - & 2 & 2 \\
\hline Researcher & - & - & - & - & - & - \\
\hline Others & - & - & - & - & - & - \\
\hline Total & - & - & 4 & 222 & 82 & 308 \\
\hline
\end{tabular}

Table 2 indicates that responses were received from people working in various positions. However, most responses were received from managers.

\subsection{Common Method Bias}

First, we checked for the presence of any common method bias (CMB), as this can affect the quality of the data and further lead to inaccurate interpretations. There are non-statistical and statistical methods to control and check for CMB. To control CMB, we designed our questionnaire carefully following the guidelines of MacKenzie \& Podsakoff (2012; Table 2, pp. 548-549), such as removing any questions that are redundant, increasing motivation by reducing the length of the survey, eliminating any form of suspicion by explaining how the information will be utilized, promising participants that names will never be disclosed and informing them that there are no right or wrong answers, and assuring them that everyone does not have the same opinion about the problems addressed in the questionnaire. These are the initiatives that were taken to control CMB during the survey. In the post-survey period, i.e., after receiving the data, we used the traditional Harman's single factor test and found that the first factor accounted for less than 50 percent of the variance. This clearly shows that CMB is not a problem in our data and we can safely use the data for hypothesis testing. 


\subsection{Non-Response Bias}

A non-response bias test was performed since we received the responses in multiple phases. In the first phase, we received 114 responses (early wave) and in the second phase, we received 194 responses (late wave). Using SPSS software, we analyzed the homogeneity of variance test and found that none of the values were significant and concluded that the data obtained in both waves were not different.

\subsection{Control Variables}

Two control variables were considered in this study. The first one is the industry and the second is the firm size. To properly account for the differences between firms, we considered "firm size" (number of employees). This is because larger firms have higher resource sets and the ability to develop better sustainability practices than smaller firms. Also, we controlled "industry" using dummy variables to distinguish between different industries (mines and quarries vs. mineral processing) (Dubey et al., 2019).

\section{DATA ANALYSIS}

The data analysis is presented in this section. The fundamental differences between co-variance based SEM and variance-based SEM were indicated in the study of Hair Jr. et al. (2017). Since our research objective is to maximize the variance explained in the endogenous variable (Hair et al., 2012); and additionally, our sample size is small, therefore, we chose to use PLS-SEM in this study. Literature shows that a similar method was used in previous research (e.g. Bag et al., 2021a, b).

\subsection{Measurement Model}

Initially, the measurement model was developed and all model fit and quality indices were tested (see Table 3).

It is recommended that the $p$ values for APC, ARS, and AARS be less than or equal to 0.05 to be significant at the 0.05 level (Kock, 2015).

The composite reliability of the constructs were checked and found to be acceptable as it was more than the threshold value of 0.70 (Hair et al., 1998) (see Appendix).

Discriminant validity was accessed using the conditions indicated by Fornell \& Larker (1981). Concerning this, the square root of AVE values and their inter-construct correlations were computed

Table 3. Model fit and quality indices

\begin{tabular}{|l|l|}
\hline \multicolumn{1}{|c|}{ Model fit and quality indices } & \multicolumn{1}{c|}{ Values } \\
\hline Average path coefficient (APC) & $0.372, \mathrm{P}<0.001$ \\
\hline Average R-squared (ARS) & $0.361, \mathrm{P}<0.001$ \\
\hline Average adjusted R-squared (AARS) & $0.357, \mathrm{P}<0.001$ \\
\hline Average block VIF (AVIF) & 1.468, acceptable if $<=5$, ideally $<=3.3$ \\
\hline Average full collinearity VIF (AFVIF) & 1.604, acceptable if $<=5$, ideally $<=3.3$ \\
\hline Tenenhaus GoF (GoF) & 0.425, small $>=0.1$, medium $>=0.25$, large $>=0.36$ \\
\hline Sympson's paradox ratio (SPR) & 1.000, acceptable if $>=0.7$, ideally $=1$ \\
\hline R-squared contribution ratio (RSCR) & 1.000, acceptable if $>=0.9$, ideally $=1$ \\
\hline Statistical suppression ratio (SSR) & 0.778, acceptable if $>=0.7$ \\
\hline $\begin{array}{l}\text { Nonlinear bivariate causality direction ratio } \\
\text { (NLBCDR) }\end{array}$ & 0.778, acceptable if $>=0.7$ \\
\hline
\end{tabular}


(see Table 4). All construct square root of AVE values were found to be above their inter-construct correlations (Fornell \& Larker, 1981), and supported the condition of discriminant validity accordingly.

Q-squared coefficients were used to check predictive validity linked with every latent variable block in the model through the endogenous latent variable: ETT (0.415), ETA (0.174), SBP (0.359), FIP (0.538), DBA (0.309). The values are acceptable as they are above zero (Kock, 2015).

\subsection{Structural Model}

The full structural model is presented below. We considered the 95\% confidence interval, and Figure 2 shows the $p$-value and path coefficient. As per the findings, all the hypotheses are supported (see Table 5).

\section{DISCUSSION}

Previous research has backed up the value of ethical leadership in the workplace. A company must focus on ethical leadership to be sustainable. Employee commitment is positively linked to ethical

Table 4. Correlations among latent variables with square roots of AVEs

\begin{tabular}{|l|l|l|l|l|l|l|l|l|}
\hline & ORT & ETL & ETT & ETA & SBP & FIP & VCC & DBA \\
\hline ORT & $\mathbf{0 . 6 2 3}$ & & & & & & & \\
\hline ETL & 0.312 & $\mathbf{0 . 5 6 4}$ & & & & & & \\
\hline ETT & 0.336 & 0.508 & $\mathbf{0 . 5 5 4}$ & & & & & \\
\hline ETA & 0.277 & 0.367 & 0.413 & $\mathbf{0 . 8 1 5}$ & & & & \\
\hline SBP & -0.047 & 0.096 & -0.028 & 0.094 & $\mathbf{0 . 8 0 0}$ & & & \\
\hline FIP & 0.003 & 0.176 & 0.019 & 0.149 & 0.662 & $\mathbf{0 . 6 8 4}$ & & \\
\hline VCC & -0.013 & 0.055 & 0.037 & 0.144 & 0.379 & 0.444 & $\mathbf{0 . 7 7 0}$ & \\
\hline DBA & -0.080 & 0.003 & 0.009 & 0.123 & 0.378 & 0.489 & 0.424 & $\mathbf{0 . 7 9 1}$ \\
\hline
\end{tabular}

Figure 2. Model after PLS-SEM analysis

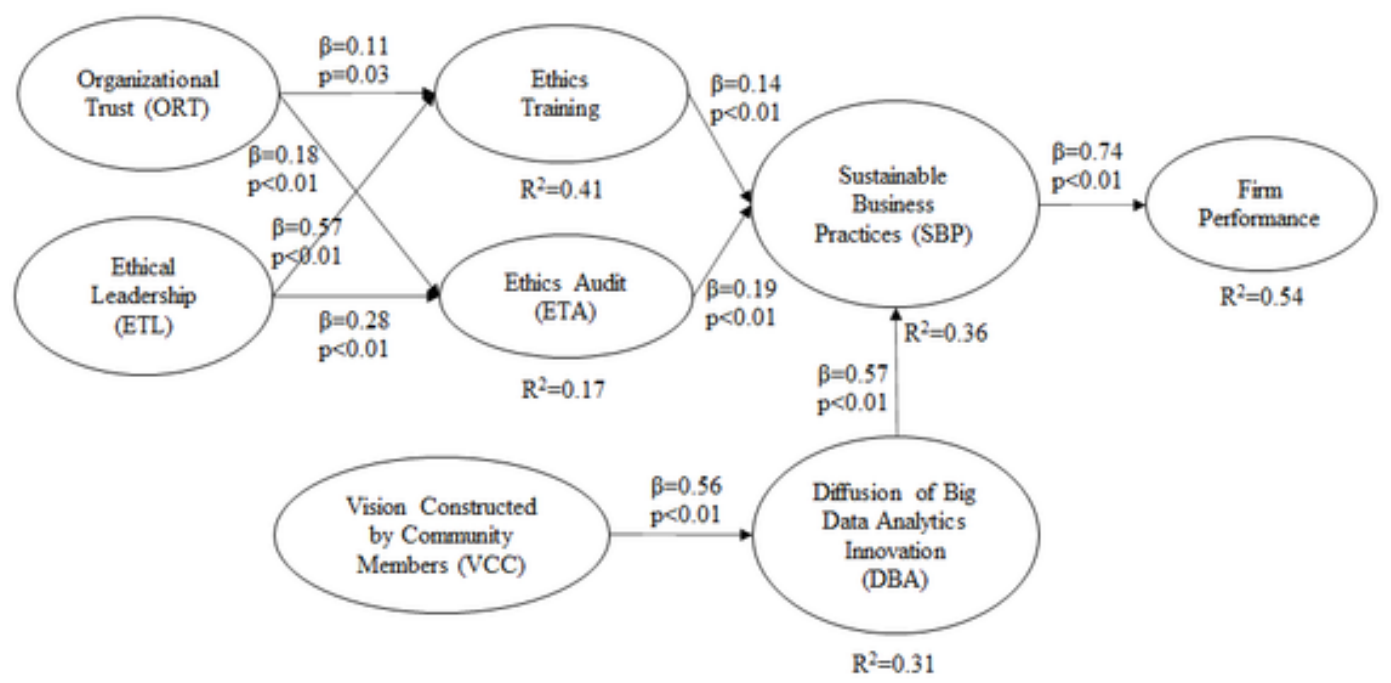


Table 5. The outcome of hypothesis testing

\begin{tabular}{|l|l|l|l|l|}
\hline \multicolumn{1}{|c|}{ No. } & \multicolumn{1}{c|}{ Research Hypotheses } & \multicolumn{1}{c|}{$\boldsymbol{\beta}$ value } & \multicolumn{1}{c|}{ p-value } & \multicolumn{1}{c|}{ Decision } \\
\hline H1 & Organizational trust $\rightarrow$ ethics training & 0.11 & 0.03 & Supported \\
\hline H2 & Organizational trust $\rightarrow$ ethics audit & 0.18 & $<.01$ & Supported \\
\hline H3 & Ethical leadership $\rightarrow$ ethics training & 0.57 & $<.01$ & Supported \\
\hline H4 & Ethical leadership $\rightarrow$ ethics audit & 0.28 & $<.01$ & Supported \\
\hline H5 & Ethics training $\rightarrow$ sustainable business practices & 0.14 & $<.01$ & Supported \\
\hline H6 & Ethics audit $\rightarrow$ sustainable business practices & 0.19 & $<.01$ & Supported \\
\hline H7 & $\begin{array}{l}\text { Vision constructed by community members } \rightarrow \\
\text { diffusion of big data analytics innovation }\end{array}$ & 0.56 & $<.01$ & Supported \\
\hline H8 & $\begin{array}{l}\text { Diffusion of big data analytics innovation } \rightarrow \\
\text { sustainable business practices }\end{array}$ & 0.57 & $<.01$ & Supported \\
\hline H9 & $\begin{array}{l}\text { Sustainable business practice } \rightarrow \text { firm } \\
\text { performance }\end{array}$ & 0.74 & $<.01$ & Supported \\
\hline
\end{tabular}

leadership, which is mediated by organizational trust. Inside an organization, leaders have good organizational relationships with their subordinates. Employees are more engaged because their leaders are ethical (Ilyas et al., 2020). The findings show that organizational trust is positively related to ethics training. Thus, H1 is supported.

Ethical leadership builds employee trust in the organization and encourages them to participate in ethics training. The value and effect of organizational trust on ethics training were shown in this report. The results indicate that organizational trust has a significant positive impact on ethics training, which is critical in South Africa's mining industry. Ethical values improve an organization's trustworthiness. Organizational trust is essential for the promotion of ethical principles within the company (Brown et al., 2005). An ethics audit is carried out to keep track of and improve a company's code of conduct. Ethics auditing is a continual mechanism that ensures that an organization's ethical values are upheld (Everett \& Tremblay, 2014). The findings show that organizational trust is positively related to ethics audits. Thus, $\mathrm{H} 2$ is supported.

The constructive relationship between organizational trust and ethics audits is shown in this study. Organizational trust leads to ethics audits, according to empirical evidence. Low employee interest in a company is a result of unethical leadership, which harms work efficiency. Employee participation is moderated by ethical leadership, which is a critical moderating element. Highly ethical leadership maintains workforce motivation and enables the company to accomplish its objectives (Joplin et al., 2021). The relationship between a leader's understanding and an ethics program's ethical training is a valuable mechanism for improving ethical behavior in an organization. Organizations are concerned with instilling integrity in their workers, so they have routine ethics training sessions. (Remišová et al., 2019). The findings show that ethical leadership is positively related to ethics training. Thus, H3 is supported.

The findings of this study identified a connection between ethical leadership and ethics training. To increase productivity, ethical leadership in South Africa's mining industry should provide ethical training to workers. Employees in the mining industry will not be able to increase efficiency until an ethical code of ethics is established through ethics training. In the long term, ethical leadership is critical to a company's success. By performing an ethics audit, the leadership is responsible for evaluating the ethical standards of an organization (Liu \& Ren, 2017). The findings show that ethical leadership is positively related to ethics audits. Thus, H4 is supported. 
The findings of this study show a positive relationship between ethical leadership and ethics audits. The ethical leadership must perform an ethics audit to preserve ethical values in the mining industry. Ethical activities may help an organization achieve long-term success. Artificial intelligence plays a critical role in enhancing the integrity of ethical activities within an enterprise in today's modern world. The importance of ethical practices in achieving sustainable development is changing as a result of technological advancements (Di Vaio et al., 2020). The findings show that ethics training is positively related to sustainable business practices. Thus, H5 is supported.

This study makes a significant contribution by demonstrating the connection between ethics training and sustainable business practices. Ethics training helps people cultivate positive values, which leads to more sustainable business practices in the long term. An ethics audit is necessary to keep track of an organization's code of conduct and ethical principles. Ethics is a necessary component of an organization's success. (Vanclay et. al., 2013). An ethics audit is essential to improving an organization's work environment. (Bringselius, 2018). The findings show that ethics audits are positively related to sustainable business practices. Thus, H6 is supported.

By proving H1, H2, H3, H4, H5 and H6 we have answered RQ1 and thereby filled the existing research gap. Our study highlights how the organizational trust and ethical leadership are helping in shaping sustainable business practices and the final impact on firm performance in the South African mining industry.

Ethics audits are essential to ensuring sustainable business practices in South Africa's mining industry, according to this empirical study. Ethics audits also improve transparency in the mining sector, which is truly needed. Big data analytics raise the bar for ethical behavior among a company's workers. They also improve the organization's accountability among all of its stakeholders. The diffusion of big data facilitates the creation of an organization's ethical framework. (Fairfield \& Shtein, 2014). Chang (2020) created an ethical framework to assess smart-city ethical and emerging challenges. Big data improves clarity and supports the monitoring of ethical principles. The findings show that the vision constructed by community members is positively related to the diffusion of big data analytics innovation. Thus, $\mathrm{H} 7$ is supported.

The relationship between community members' visions and the diffusion of big data analytics innovation is further explored in this article. According to this study, both are positively associated. Big data analytics affects companies' sustainable business practices. Big data support the evaluation of successful policies for businesses, resulting in more sustainable business practices. Big data will be used to correlate sustainable business practices to sustainable business performance (Raut et al., 2019). The findings show that the diffusion of big data analytics innovation is positively related to sustainable business practices. Thus, H8 is supported.

It proves that the diffusion of big data analytics has a positive impact on sustainable business practices. It indicates that the mining industry in South Africa should use big data analytics to enhance the efficiency of business practices. The adoption of sustainable business practices improves the organization's performance. To improve firm performance in a highly competitive market, sustainable business practices are needed. (Cantele \& Cassia, 2020). Stakeholders are influenced by sustainability to develop environmental responsibility. The development of a positive climate is critical to improving the firm's performance. The findings show that sustainable business practices are positively related to firm performance. Thus, H9 is supported.

By proving H7, H8 and H9 we have answered RQ2 and thereby filled the existing research gap. Our study highlights how can the vision constructed by community members aid in the diffusion of big data analytics innovation.

The mining industry in South Africa urgently needs sustainable business practices. Both control variables (industry and firm size) were found to be statistically non-significant.

To the best of the researcher's knowledge, this is the first study of its kind to consider ethical issues in the context of the South African mining industry and to also examine how the diffusion 
of big data analytics innovation can improve sustainability aspects. Thus, our study advances the theoretical debate.

\subsection{Theoretical Implications}

We answered both research questions in this study and ensured that the work makes a strong contribution to the field of supply chain management. Although we have not developed a theory from scratch in this work, we put a significant amount of effort into improving the existing knowledge by pushing the theoretical boundaries.

The main theme of this study revolves around the ethical climate, organizational practices, and their consequences, as well as the vision constructed by community members in the diffusion of big data analytics innovation. Ultimately, all of this leads to sustainable business practices in the mining industry and also enhances firm performance. The study extends the knowledge base in two ways: first, we empirically validated the theoretical model using evidence from the South African mining industry. Second, we highlighted how the ethical theory of organization can be extended by incorporating a technological diffusion/information processing component in the framework and demonstrating its influence on organizational practices to attain sustainability.

\subsection{Practical Implications}

This study provides many take-aways for managers who are working in mining and mineral processing. There is a sustainability-related concern in this industry, and the findings reveal that managers/top leaders need to shift their focus towards a) organizational trust-building and ethical leadership, and b) big data analytics, i.e., decision-making based on data.

Sustainability is a key issue in the mining industry and involves problems such as input quality compromises, inefficient processes, a lack of advanced pollution prevention technologies, long working hours, and a lack of environmental and societal aspects in many regions. Our study suggests that leaders, i.e., the top management, need to build organizational trust among key stakeholders (suppliers, shareholders, employees, customers), and second, these leaders need to demonstrate ethical leadership and empower employees to further develop governance, which will indirectly enhance sustainable business practices. Nonetheless, ethics training and ethical audits are very important and have garnered little attention from many mining and mineral processing companies, but they must understand that until and unless these two things are in place, stakeholders will not cooperate in the sustainability program. Ethics training and ethical audits will not only help the companies but also the suppliers to grow and protect nature.

Second, human decision-making may not always be $100 \%$ accurate, so data-driven decisionmaking can be an important factor in the sustainability of the mining business. Companies need to adopt big data analytics, and the findings have revealed that community pressures have directed mining companies to focus on data-driven innovation. Therefore, the vision is very important to help in the diffusion of big data analytics innovation. This will ultimately help managers and leaders of mining and mineral processing businesses to make quality decisions and enhance sustainability, which will in turn improve firm performance. Hence, the findings fill the knowledge gap between theory and practice.

\section{CONCLUSION}

Using the ethical theory of organization and organizing vision theory, we developed a theoretical framework and answered two important questions. First, what is the link between organizational trust and ethical leadership in shaping sustainable business practices, and what is the final impact on firm performance? The findings indicate that hypotheses 1 to 6 and 9 are supported based on the empirical evidence from South African mines and quarries as well as mineral production facilities. The second research question asked how the vision constructed by community members could aid 
in big data analytics innovation. The findings indicate that hypotheses 7 and 8 are supported based on the empirical evidence from South African mineral manufacturing plants, mines, and quarries. The implications for managers have been presented and we believe that this study has advanced the literature in the field of mining business sustainability. However, this study suffers from a few limitations, which include the use of a cross-sectional survey. Second, the data have been collected from one country only. Future researchers could collect data from other African countries such as Ghana and Zambia to compare the results. Future researchers could also dig deeper to examine supply chain decisions from an ethical point of view, which could impact the sustainability of the mining business. Furthermore, big data-driven artificial intelligence tools can be examined to cut down on human intervention in mining and reduce ethical concerns, resulting in enhanced sustainability.

\section{FUNDING AGENCY}

Publisher has waived the Open Access Publishing fee. 


\section{REFERENCES}

Abuzaid, A. N. (2018). The relationship between ethical leadership and organizational commitment in the banking sector of Jordan. Journal of Economic and Administrative Sciences, 34(3), 187-203. doi:10.1108/ JEAS-01-2018-0006

Alaaraj, S., Mohamed, Z. A., \& Bustamam, U. S. A. (2018). External growth strategies and organizational performance in emerging markets: The mediating role of inter-organizational trust. Review of International Business and Strategy, 28(2), 206-222. doi:10.1108/RIBS-09-2017-0079

Allen, W. R., Bacdayan, P., Kowalski, K. B., \& Roy, M. H. (2005). Examining the impact of ethics training on business student values. Education + Training, 47(3), 170-182. doi:10.1108/00400910510592220

Arel, B., Beaudoin, C. A., \& Cianci, A. M. (2012). The impact of ethical leadership, the internal audit function, and moral intensity on a financial reporting decision. Journal of Business Ethics, 109(3), 351-366. doi:10.1007/ s10551-011-1133-1

Audi, R., Loughran, T., \& McDonald, B. (2016). Trust, but verify MD\&A language and the role of trust in corporate culture. Journal of Business Ethics, 139(3), 551-561. doi:10.1007/s10551-015-2659-4

Azapagic, A. (2004). Developing a framework for sustainable development indicators for the mining and minerals industry. Journal of Cleaner Production, 12(6), 639-662. doi:10.1016/S0959-6526(03)00075-1

Badri, A., \& Boudreau-Trudel, B. (2021). Sustainable development in the mining industry: Towards the development of tools for evaluating socioeconomic impact in the Canadian context. Environment, Development and Sustainability, 23(5), 6576-6602. doi:10.1007/s10668-020-00948-y

Bag, S., Dhamija, P., Pretorius, J.H.C., Chowdhury, A.H., \& Giannakis, M. (2021). Sustainable electronic human resource management systems and firm performance: an empirical study. International Journal of Manpower. 10.1108/IJM-02-2021-0099

Bag, S., Gupta, S., Kumar, A., \& Sivarajah, U. (2021a). An integrated artificial intelligence framework for knowledge creation and B2B marketing rational decision making for improving firm performance. Industrial Marketing Management, 92(January), 178-189. doi:10.1016/j.indmarman.2020.12.001

Bag, S., Pretorius, J. H. C., Gupta, S., \& Dwivedi, Y. K. (2021b). Role of institutional pressures and resources in the adoption of big data analytics powered artificial intelligence, sustainable manufacturing practices and circular economy capabilities. Technological Forecasting and Social Change, 163(February), 120420. doi:10.1016/j. techfore. 2020.120420

Bringselius, L. (2018). Efficiency, economy and effectiveness-But what about ethics? Supreme audit institutions at a critical juncture. Public Money \& Management, 38(2), 105-110. doi:10.1080/09540962.2018.1407137

Brown, M. E., Treviño, L. K., \& Harrison, D. A. (2005). Ethical leadership: A social learning perspective for construct development and testing. Organizational Behavior and Human Decision Processes, 97(2), 117-134. doi:10.1016/j.obhdp.2005.03.002

Cantele, S., \& Cassia, F. (2020). Sustainability implementation in restaurants: A comprehensive model of drivers, barriers, and competitiveness-mediated effects on firm performance. International Journal of Hospitality Management, 87(May), 102510. doi:10.1016/j.ijhm.2020.102510

Chams-Anturi, O., Moreno-Luzon, M. D., \& Escorcia-Caballero, J. P. (2019). Linking organizational trust and performance through ambidexterity. Personnel Review, 49(4), 956-973. doi:10.1108/PR-07-2018-0239

Chang, V. (2021). An ethical framework for big data and smart cities. Technological Forecasting and Social Change, 165(April), 120559. doi:10.1016/j.techfore.2020.120559

Chong, M. P., Shang, Y., Richards, M., \& Zhu, X. (2018). Two sides of the same coin? Leadership and organizational culture. Leadership and Organization Development Journal, 39(8), 975-994. doi:10.1108/ LODJ-05-2017-0122

Delery, J. E., \& Doty, D. H. (1996). Modes of theorizing in strategic human resource management: Tests of universalistic, contingency and configurational performance predictions. Academy of Management Journal, 39(4), 802-835. doi:10.5465/256713 
Demirtas, O. (2015). Ethical leadership influence at organizations: Evidence from the field. Journal of Business Ethics, 126(2), 273-284. doi:10.1007/s10551-013-1950-5

Di Vaio, A., Palladino, R., Hassan, R., \& Escobar, O. (2020). Artificial intelligence and business models in the sustainable development goals perspective: A systematic literature review. Journal of Business Research, 121, 283-314. doi:10.1016/j.jbusres.2020.08.019

Dubey, R., Gunasekaran, A., Childe, S. J., Blome, C., \& Papadopoulos, T. (2019). Big data and predictive analytics and manufacturing performance: Integrating institutional theory, resource-based view and big data culture. British Journal of Management, 30(2), 341-361. doi:10.1111/1467-8551.12355

Dust, S. B., Resick, C. J., Margolis, J. A., Mawritz, M. B., \& Greenbaum, R. L. (2018). Ethical leadership and employee success: Examining the roles of psychological empowerment and emotional exhaustion. The Leadership Quarterly, 29(5), 570-583. doi:10.1016/j.leaqua.2018.02.002

Engelbrecht, A. S., Heine, G., \& Mahembe, B. (2017). Integrity, ethical leadership, trust and work engagement. Leadership and Organization Development Journal, 38(3), 368-379. doi:10.1108/LODJ-11-2015-0237

Everett, J., \& Tremblay, M. S. (2014). Ethics and internal audit: Moral will and moral skill in a heteronomous field. Critical Perspectives on Accounting, 25(3), 181-196. doi:10.1016/j.cpa.2013.10.002

Fairfield, J., \& Shtein, H. (2014). Big data, big problems: Emerging issues in the ethics of data science and journalism. Journal of Mass Media Ethics, 29(1), 38-51. doi:10.1080/08900523.2014.863126

Fornell, C., \& Larcker, D. F. (1981). Structural equation models with unobservable variables and measurement error. Algebra and Statistics, 18(3), 382-388.

Gaffoor, Z., Pietersen, K., Jovanovic, N., Bagula, A., \& Kanyerere, T. (2020). Big data analytics and its role to support groundwater management in the southern African development community. Water (Basel), 12(10), 1-28. doi:10.3390/w12102796

Gomez, S. R., Perez, M. V. L., Sánchez, R. G., \& Ariza, L. R. (2020). Factors in the acquisition of ethical training. Education + Training, 63(3), 472-489. doi:10.1108/ET-01-2019-0006

Goyal, P., Rahman, Z., \& Kazmi, A. A. (2013). Corporate sustainability performance and firm performance research: Literature review and future research agenda. Management Decision, 51(2), 361-379. doi:10.1108/00251741311301867

Grojean, M. W., Resick, C. J., Dickson, M. W., \& Smith, D. B. (2004). Leaders, values, and organizational climate: Examining leadership strategies for establishing an organizational climate regarding ethics. Journal of Business Ethics, 55(3), 223-241. doi:10.1007/s10551-004-1275-5

Hair, J., Anderson, R., Tatham, R., \& Black, W. (1998). Multivariate Data Analysis (5th ed.). Prentice Hall.

Hair, J. F. Jr, Matthews, L. M., Matthews, R. L., \& Sarstedt, M. (2017). PLS-SEM or CB-SEM: Updated guidelines on which method to use. International Journal of Multivariate Data Analysis, 1(2), 107-123. doi:10.1504/ IJMDA.2017.10008574

Hair, J. F., Sarstedt, M., Pieper, T. M., \& Ringle, C. M. (2012). The use of partial least squares structural equation modeling in strategic management research: A review of past practices and recommendations for future applications. Long Range Planning, 45(5-6), 320-340. doi:10.1016/j.lrp.2012.09.008

Hilson, G., \& Murck, B. (2000). Sustainable development in the mining industry: Clarifying the corporate perspective. Resources Policy, 26(4), 227-238. doi:10.1016/S0301-4207(00)00041-6

Hunt, S. D., Wood, V. R., \& Chonko, L. B. (1989). Corporate ethical values and organizational commitment in marketing. Journal of Marketing, 53(3), 79-90.

Iftikhar, R., \& Khan, M. S. (2020). Social media big data analytics for demand forecasting: Development and case implementation of an innovative framework. Journal of Global Information Management, 28(1), 103-120.

Ilyas, S., Abid, G., \& Ashfaq, F. (2020). Ethical leadership in sustainable organizations: The moderating role of general self-efficacy and the mediating role of organizational trust. Sustainable Production and Consumption, 22(April), 195-204. 
Joplin, T., Greenbaum, R. L., Wallace, J. C., \& Edwards, B. D. (2021). Employee entitlement, engagement, and performance: The moderating effect of ethical leadership. Journal of Business Ethics, 168, 813-826. https:// doi.org/10.1007/s10551-019-04246-0

Kancharla, R., \& Dadhich, A. (2021). Perceived ethics training and workplace behavior: The mediating role of perceived ethical culture. European Journal of Training and Development, 45(1), 53-73.

Kaplan, D. (2012). South African mining equipment and specialist services: Technological capacity, export performance and policy. Resources Policy, 37(4), 425-433.

Kim, I., \& Miranda, S. M. (2018). 20 Years Old but Still a Teenager? A Review of Organizing Vision Theory and Suggested Directions. In PACIS (pp. 23). https://aisel.aisnet.org/pacis2018/23

Kock, N. (2015). WarpPLS 5.0 user manual. ScriptWarp Systems.

Kusi-Sarpong, S., Sarkis, J., \& Wang, X. (2016). Assessing green supply chain practices in the Ghanaian mining industry: A framework and evaluation. International Journal of Production Economics, 181(Part B), 325-341.

Laing, T., Upadhyay, A., Mohan, S., \& Subramanian, N. (2019). Environmental improvement initiatives in the coal mining industry: Maximisation of the triple bottom line. Production Planning and Control, 30(5-6), 426-436.

Laskar, N., \& Maji, S. G. (2018). Disclosure of corporate sustainability performance and firm performance in Asia. Asian Review of Accounting, 26(4), 414-443.

Leonard, L. (2019). Traditional leadership, community participation and mining development in South Africa: The case of Fuleni, Saint Lucia, KwaZulu-Natal. Land Use Policy, 86(July), 290-298.

Liu, G., \& Ren, H. (2017). Ethical team leadership and trainee auditors' likelihood of reporting client's irregularities. Journal of Financial Crime, 24(1), 157-175.

MacKenzie, S. B., \& Podsakoff, P. M. (2012). Common method bias in marketing: Causes, mechanisms, and procedural remedies. Journal of Retailing, 88(4), 542-555.

Marais, L., McKenzie, F. H., Deacon, L., Nel, E., van Rooyen, D., \& Cloete, J. (2018). The changing nature of mining towns: Reflections from Australia, Canada and South Africa. Land Use Policy, 76(July), 779-788.

Maroufkhani, P., Tseng, M. L., Iranmanesh, M., Ismail, W. K. W., \& Khalid, H. (2020). Big data analytics adoption: Determinants and performances among small to medium-sized enterprises. International Journal of Information Management, 54(October), 102190. https://doi.org/10.1016/j.ijinfomgt.2020.102190

Mayer, D. M., Aquino, K., Greenbaum, R. L., \& Kuenzi, M. (2012). Who displays ethical leadership, and why does it matter? An examination of antecedents and consequences of ethical leadership. Academy of Management Journal, 55(1), 151-171.

Mehta, A. M., Tam, L., Greer, D. A., \& Letheren, K. (2020). Before crisis: How near-miss affects organizational trust and industry transference in emerging industries. Public Relations Review, 46(2), 101886. https://doi. org/10.1016/j.pubrev.2020.101886

Mikalef, P., Boura, M., Lekakos, G., \& Krogstie, J. (2019). Big data analytics and firm performance: Findings from a mixed-method approach. Journal of Business Research, 98(May), 261-276.

Miranda, S. M., Kim, I., \& Summers, J. D. (2015). Jamming with Social Media. Management Information Systems Quarterly, 39(3), 591-614.

Mishra, D., Luo, Z., \& Hazen, B. T. (2018). The role of informational and human resource capabilities for enabling diffusion of big data and predictive analytics and ensuing performance. In Innovation and Supply Chain Management (pp. 283-302). Springer. https://doi.org/10.1007/978-3-319-74304-2_13.

Nedkovski, V., Guerci, M., De Battisti, F., \& Siletti, E. (2017). Organizational ethical climates and employee's trust in colleagues, the supervisor, and the organization. Journal of Business Research, 71(February), 19-26.

Özgener, Ş. (2009). İş ahlakının temelleri yönetsel bir yaklaşım. Nobel Akademik Yayıncılık.

Padin, C., Ferro, C., Wagner, B., Valera, J. C. S., Høgevold, N. M., \& Svensson, G. (2016). Validating a triple bottom line construct and reasons for implementing sustainable business practices in companies and their business networks. Corporate Governance, 16(5), 849-865. 
Papadopoulos, T., Gunasekaran, A., Dubey, R., Altay, N., Childe, S. J., \& Fosso-Wamba, S. (2017). The role of Big Data in explaining disaster resilience in supply chains for sustainability. Journal of Cleaner Production, 142(Part 2), 1108-1118.

Pučètaitè, R. (2014). Stimulating organizational innovativeness through ethical leadership practices: The mediating role of organizational trust. Procedia: Social and Behavioral Sciences, 156(November), 231-235.

Raut, R. D., Mangla, S. K., Narwane, V. S., Gardas, B. B., Priyadarshinee, P., \& Narkhede, B. E. (2019). Linking big data analytics and operational sustainability practices for sustainable business management. Journal of Cleaner Production, 224(July), 10-24.

Remišová, A., Lašáková, A., \& Kirchmayer, Z. (2019). Influence of formal ethics program components on managerial ethical behavior. Journal of Business Ethics, 160(1), 151-166.

Ren, S., Zhang, Y., Liu, Y., Sakao, T., Huisingh, D., \& Almeida, C. M. (2019). A comprehensive review of big data analytics throughout product lifecycle to support sustainable smart manufacturing: A framework, challenges and future research directions. Journal of Cleaner Production, 210(February), 1343-1365.

Schoorman, F. D., Mayer, R. C., \& Davis, J. H. (2007). An integrative model of organizational trust: Past, present, and future. Academy of Management Review, 32(2), 344-354.

Schrettle, S., Hinz, A., Scherrer-Rathje, M., \& Friedli, T. (2014). Turning sustainability into action: Explaining firms' sustainability efforts and their impact on firm performance. International Journal of Production Economics, 147(Part A), 73-84.

Singh, S. K., Chen, J., Del Giudice, M., \& El-Kassar, A. N. (2019). Environmental ethics, environmental performance, and competitive advantage: Role of environmental training. Technological Forecasting and Social Change, 146(September), 203-211.

Song, M. L., Fisher, R., Wang, J. L., \& Cui, L. B. (2018). Environmental performance evaluation with big data: Theories and methods. Annals of Operations Research, 270(1), 459-472.

Spangenberg, H., \& Theron, C. C. (2005). Promoting ethical follower behaviour through leadership of ethics: The development of the ethical leadership inventory (ELI). South African Journal of Business Management, 36(2), 1-18.

Standing, S., Standing, C., Love, P. E., \& Gengatharen, D. (2017). The multiplicity of organizing visions. Industrial Marketing Management, 66(October), 196-204.

Sterling, S., \& Gass, S. (2017). Exploring the boundaries of research ethics: Perceptions of ethics and ethical behaviors in applied linguistics research. System, 70(November), 50-62.

Sterling, S., \& Gass, S. (2017). Exploring the boundaries of research ethics: Perceptions of ethics and ethical behaviors in applied linguistics research. System, 70(November), 50-62.

Svensson, G., Wood, G., \& Callaghan, M. (2010). A corporate model of sustainable business practices: An ethical perspective. Journal of World Business, 45(4), 336-345.

Vanclay, F., Baines, J. T., \& Taylor, C. N. (2013). Principles for ethical research involving humans: Ethical professional practice in impact assessment Part I. Impact Assessment and Project Appraisal, 31(4), 243-253.

Vélez, M. L., Sánchez, J. M., \& Álvarez-Dardet, C. (2008). Management control systems as inter-organizational trust builders in evolving relationships: Evidence from a longitudinal case study. Accounting, Organizations and Society, 33(7-8), 968-994.

Wolfert, S., Ge, L., Verdouw, C., \& Bogaardt, M. J. (2017). Big data in smart farming-a review. Agricultural Systems, 153(May), 69-80.

Yazdani, N., \& Murad, H. S. (2015). Toward an ethical theory of organizing. Journal of Business Ethics, 127(2), 399-417.

Yoo, D., \& Roh, J. J. (2021). Value chain creation in business analytics. Journal of Global Information Management, 29(4), 131-147.

Zulkefly, N. A., Ghani, N. A., Hamid, S., Ahmad, M., \& Gupta, B. B. (2021). Harness the Global Impact of Big Data in Nurturing Social Entrepreneurship: A Systematic Literature Review. Journal of Global Information Management, 29(6), 1-19. 


\section{APPENDIX}

\section{Table 6. Operationalisation of constructs}

\begin{tabular}{|c|c|c|}
\hline Construct & Items & Composite Reliability $>0.70$ \\
\hline \multirow{5}{*}{$\begin{array}{l}\text { Organizational Trust (ORT) } \\
\text { (Schoorman et al., 2007) }\end{array}$} & My administrator keeps my interface in intellect when making choices & \multirow{5}{*}{0.775} \\
\hline & $\begin{array}{l}\text { I would be willing to let my boss have total control over my future in } \\
\text { this organization }\end{array}$ & \\
\hline & $\begin{array}{l}\text { In case my boss inquired why an issue happened, I would talk } \\
\text { unreservedly indeed in case I were incompletely to fault }\end{array}$ & \\
\hline & $\begin{array}{l}\text { I feel comfortable being imaginative since my supervisor gets it that } \\
\text { some of the time inventive arrangement don't work }\end{array}$ & \\
\hline & $\begin{array}{l}\text { It is imperative for me to have a great way to keep an eye on my } \\
\text { supervisor }\end{array}$ & \\
\hline \multirow{9}{*}{$\begin{array}{l}\text { Ethical Leadership (ETL) } \\
\text { (Mayer et al., 2012) }\end{array}$} & My office chief tunes in to what division workers have to be said & \multirow{9}{*}{0.802} \\
\hline & My office chief disciplines workers who abuse moral standards & \\
\hline & My division supervisor has the leading interface of workers in mind & \\
\hline & My office director makes reasonable and adjusted choices & \\
\hline & My department manager is reliable & \\
\hline & My manager examines trade morals or values with representatives & \\
\hline & $\begin{array}{l}\text { My division supervisor sets a case of how to do things the correct way } \\
\text { in terms of morals }\end{array}$ & \\
\hline & $\begin{array}{l}\text { My department manager defines success not just by results but also } \\
\text { the way they are gotten }\end{array}$ & \\
\hline & $\begin{array}{l}\text { My office supervisor inquires "what is the proper thing to do?" when } \\
\text { making choices }\end{array}$ & \\
\hline \multirow{8}{*}{$\begin{array}{l}\text { Ethics Trainings (ETT) (Hunt et } \\
\text { al., 1989; Delery \& Doty, 1996) }\end{array}$} & $\begin{array}{l}\text { Supervisors in my company don't lock in behaviors that I consider to } \\
\text { be untrustworthy }\end{array}$ & \multirow{8}{*}{0.776} \\
\hline & To succeed in my company, it isn't fundamental to compromise one's morals & \\
\hline & $\begin{array}{l}\text { Higher management signals that deceptive behaviors will not be } \\
\text { endured indeed in questionable terms }\end{array}$ & \\
\hline & $\begin{array}{l}\text { On the off chance that a supervisor in my company is found to have } \\
\text { locked in deceptive behavior that results in individual pick up, he or } \\
\text { she will be instantly reprimanded }\end{array}$ & \\
\hline & Broad preparing programs are given for people in my work & \\
\hline & $\begin{array}{l}\text { There are formal training programs to teach new hires, the skills they } \\
\text { need to perform their jobs }\end{array}$ & \\
\hline & $\begin{array}{l}\text { There are formal preparing programs for employees to upsurge their } \\
\text { promotability in this company }\end{array}$ & \\
\hline & $\begin{array}{l}\text { Workers in this work will regularly go through preparing programs } \\
\text { each few years }\end{array}$ & \\
\hline \multirow{2}{*}{$\begin{array}{l}\text { Ethics Audit (ETA) (Yazdani \& } \\
\text { Murad, 2015) }\end{array}$} & $\begin{array}{l}\text { Ethical audits are considered a 'key management } \\
\text { tool' in this organization }\end{array}$ & \multirow{2}{*}{0.798} \\
\hline & $\begin{array}{l}\text { Moral reviews are utilized to gauge the level of ethical advancement, } \\
\text { value, and other components of moral culture in this company }\end{array}$ & \\
\hline \multirow{4}{*}{$\begin{array}{l}\text { Sustainable Business Practices } \\
\text { in Mining Companies (SBP) } \\
\text { (Padin et al., 2016) }\end{array}$} & $\begin{array}{l}\text { We make the foremost proficient utilize of the assets accessible within } \\
\text { the environment }\end{array}$ & \multirow{4}{*}{0.876} \\
\hline & We rest on financial contemplations & \\
\hline & We consider the social well-being of society as an entirely & \\
\hline & We focus on social (i.e., relational or societal) facets & \\
\hline
\end{tabular}


Table 6. Continued

\begin{tabular}{|c|c|c|}
\hline Construct & Items & Composite Reliability $>0.70$ \\
\hline \multirow{7}{*}{$\begin{array}{l}\text { Firm Performance (FIP) } \\
\text { (Yazdani \& Murad, 2015) }\end{array}$} & Expanded ethical viability & \multirow{7}{*}{0.855} \\
\hline & Improved stakeholders' faith & \\
\hline & Improved organizational rightfulness & \\
\hline & Increase firm reputation & \\
\hline & Improved employee retaining & \\
\hline & Improved customer retention/ faithfulness & \\
\hline & Improved profitability & \\
\hline \multirow{2}{*}{$\begin{array}{l}\text { Vision Constructed by } \\
\text { Community Members (VCC) } \\
\text { (Standing et al., 2017) }\end{array}$} & $\begin{array}{l}\text { The coerced community develops a coercion mechanism that forces } \\
\text { the use of BDA through economic or political pressure }\end{array}$ & \multirow{2}{*}{0.744} \\
\hline & $\begin{array}{l}\text { Coercion forces play an important role in BDA adoption for } \\
\text { sustainable mining business }\end{array}$ & \\
\hline \multirow{7}{*}{$\begin{array}{l}\text { Diffusion of Big Data Analytics } \\
\text { Innovation (DBA) (Mishra et } \\
\text { al., 2018) }\end{array}$} & Supporting production and operations management & \multirow{7}{*}{0.920} \\
\hline & Supporting warehousing and inventory management & \\
\hline & Supporting reduction in greenhouse gas emissions & \\
\hline & Supporting energy savings and natural resources & \\
\hline & Supporting improvement in the safety of the work environment & \\
\hline & Supporting restoration of initial environmental conditions & \\
\hline & Supporting minimization of the impacts to the environment & \\
\hline
\end{tabular}

Surajit Bag is an Associate Professor at Rabat Business School with a strong track record in higher education. Prior to joining academia, he has served manufacturing industries of repute for eleven years at various senior positions. Educationally, he has earned his second PhD in Engineering Management from the University of Johannesburg, South Africa, and holds a first PhD from the University of Petroleum and Energy Studies, India. His expertise lies in the areas of Industry 4.0, Supply Chain Management, and Circular Economy. He has published several research papers in leading technology and operations management journals. He is the proud recipient of "AIMS-IRMA Young Management Researcher Award 2016". Editorially, he is an Associate Editor of International Journal of Applied Logistics.

Gautam Srivastava is working as an Assistant Professor at GL Bajaj Institute of Management and Research, Greater Noida. He has more than 15 years of academic experience. He has earned his PhD from the School of Business, University of Petroleum and Energy Studies, India. His area of specialization is Business Statistics and Marketing. His research has been published in various national and international journals.

Shivam Gupta is a Professor at NEOMA Business School, France with a demonstrated history of working in the higher education industry. Skilled in Statistics, Cloud Computing, Big Data Analytics, Artificial Intelligence and Sustainability. Strong education professional with a Doctor of Philosophy (PhD) focused in Cloud Computing and Operations Management from Indian Institute of Technology (IIT) Kanpur. Followed by PhD, postdoctoral research was pursued at Freie Universität Berlin and SUSTech, China. He has completed HDR from University of Montpellier, France. He has published several research papers in reputed journals and has been the recipient of the International Young Scientist Award by the National Natural Science Foundation of China (NSFC) in 2017 and winner of the 2017 Emerald South Asia LIS award.

Saito Taiga is an Assistant Professor at the Graduate School of Economics, The University of Tokyo, Japan. His research interests are in the domain of modeling market participants' trading behaviors and their interactions in financial markets through quantitative approaches that utilize stochastic control theories as tools. His research is also focused on information management for corporations, such as revenue management, and using big data through quantitative modeling. 